\title{
DETERMINAN LINGKUNGAN FISIK RUMAH TERHADAP PNEUMONIA PADA BALITA DI PINGGIRAN SUNGAI MUSI
}

\author{
Gananda Prajadiva ${ }^{1}$, Yustini Ardillah ${ }^{2} *$ \\ ${ }^{1}$ Program Studi Kesehatan Masyarakat, FKM Universitas Sriwjaya \\ Email: ${ }^{1}$ gprajadiva@gmail.com \\ ${ }^{2}$ Program Studi Kesehatan Lingkungan, FKM Universitas Sriwjaya \\ Corresponding Email: ${ }^{2 *}$ yustiniardillah@ gmail.com \\ *corresponding author
}

\begin{abstract}
Abstrak
Daerah pinggiran sungai Musi merupakan daerah yang masuk sebagai daerah kumuh di Kota Palembang. Kasus pneumonia di Kota Palembang banyak ditemukan di daerah ini. Tujuan penelitian ini adalah untuk mengetahui determinan lingkungan fisik rumah dengan kejadian pneumonia. Penelitian ini merupakan penelitian observasi dengan metode kasus kontrol. Terdapat 78 sampel yang terdiri dari 26 kasus dan 52 kontrol dengan kriteria inklusi dan eksklusi. Data pada penelitian ini dikumpulkan dengan metode wawancara dan pengukuran. Analisis data menggunakan uji chi square dan analisis regresi logistic ganda. Hasil analisis data menunjukkan dari 10 variabel yang diteliti terdapat 7 variabel yang berhubungan yaitu riwayat pemberian ASI eksklusif [OR=3,022 (95\%CI; 1,132-8,071)], luas ventilasi $[\mathrm{OR}=3,167(95 \% \mathrm{CI} ; 1.138-8,815)]$, kepadatan hunian rumah $[\mathrm{OR}=3,422(95 \% \mathrm{CI} ; 1,228-9,538)]$, pencahayaan $[\mathrm{OR}=5,588$ $(95 \% \mathrm{CI} ; 1,970-15,849)]$, suhu [OR=3,947 (95\%CI; 1,463-10,643)], kelembaban $[\mathrm{OR}=3,422 \quad(95 \% \mathrm{CI} ; 1,228-9,538)]$ dan keberadaan anggota keluarga yang merokok [OR=0,034 (95\%CI; 1,216-13,378)]. Berdasarkan hasil analisis multivariat, variabel pencahayaan merupakan variabel yang paling berhubungan dengan Odds Ratio 10,165; 95\% CI 1,887 - 54,743. Rumah tangga dengan kondisi lingkungan yang masih belum memenuhi syarat seperti tingkat pencahayaan yang minim dapat berisiko menyebabkan terjadinya pneumonia pada balita.
\end{abstract}

Kata kunci : Case Control, Pneumonia, Sungai Musi

\begin{abstract}
Musi bank river is a slum area. The highest pneumonia cases among balita was in that area. This study aimed to analyzed determinant of residential factors for pneumonia childhood. This study was an observational research with a case control design. There were 78 samples consisted of 26 cases and 52 controls in inclusion and exclusion criteria. Data were collected through interviews and measurements. Analyzed using chi square test and multiple logistic regression. The results show from 10 variables studied are 7 variables related, exclusive breastfeeding history $[\mathrm{OR}=3,022$ (95\%CI; 1,132-
\end{abstract}


8,071)], size of ventilation [OR=3,167 (95\%CI; $1.138-8,815)]$, housing density $[\mathrm{OR}=3,422 \quad(95 \% \mathrm{CI} ; 1,228-9,538)]$, lighting $[\mathrm{OR}=5,588(95 \% \mathrm{CI} ; 1,970-15,849)]$, temperature $[\mathrm{OR}=3,947(95 \% \mathrm{CI}$; $1,463-10,643)]$, humidity [OR=3,422 (95\%CI; 1,228-9,538)], and the presence of smokers [OR=0,034 $(95 \% \mathrm{CI} ; 1,216-13,378)]$. According to multivariate analysis, there was a dominant variable that was lighting with Odds Ratio 10,165; 95\% CI 1,887 to 54,743. People with house environmental conditions that are not qualified such as minimal lighting levels can cause pneumonia on under five years old children.

Keywords: Case Control, Musi River, Pneumonia

\section{PENDAHULUAN}

Pemukiman kumuh merupakan masalah yang dihadapi oleh hampir semua kota-kota besar di Indonesia, bahkan kotakota besar di negara berkembang lainnya. Pemukiman kumuh merupakan permukiman yang tidak layak huni karena ketidakteraturan bangunan, tingkat kepadatan bangunan yang tinggi, dan kualitas bangunan serta sarana dan prasarana yang tidak memenuhi syarat. Perumahan kumuh adalah perumahan yang mengalami penurunan kualitas fungsi sebagai tempat hunian (WHO, 2010). Pemukiman kumuh umumnya dihubungkan dengan tingkat kemiskinan dan pengangguran tinggi. Dari segi kondisi fisiknya, pemukiman kumuh erat kaitannya dengan bangunan yang sangat rapat, sanitasi umum dan drainase tidak berfungsi serta sampah belum dikelola dengan baik. Hal ini berdampak pada kondisi kesehatan yang buruk karena adanya sumber pencemaran dan penyebaran penyakit.

Pneumonia saat ini masih menjadi penyebab utama kematian pada anak balita di seluruh dunia, tercatat dalam 1,6 juta kematian anak dibawah 5 tahun terdapat $18 \%$ merupakan karena pneumonia. Kematian karena pneumonia pada balita sangat terkait dengan kekurangan gizi, kemiskinan, lingkungan, dan akses terhadap pelayanan kesehatan yang tidak memadai. Pneumonia banyak ditemukan pada negara dengan pendapatan menengah kebawah salah satunya di Asia dan Afrika (WHO, 2016). Di negara berkembang seperti Indonesia, pneumonia merupakan penyebab urutan kedua setelah diare pada kematian balita. Terjadi peningkatan kejadian pneumonia yang dilaporkan pada tahun 2007 sebesar 2,1\% menjadi 2,7\% pada tahun 2013 (Kemenkes, 2013). Provinsi Sumatera Selatan merupakan salah satu Provinsi di Indonesia dengan tingkat prevalensi pneumonia cukup tinggi. Jumlah temuan kasus pneumonia di Sumatera Selatan pada tahun 2016 adalah sebesar 17.384 dengan cakupan penanganan sebesar 47,28\% (Dinkes Palembang, 2016).

Profil Kesehatan Kota Palembang menyatakan pneumonia masih menjadi masalah kesehatan masyarakat pada balita di Kota Palembang, dari tahun 2011 sampai dengan tahun 2015 jumlah kasus pneumonia di Kota Palembang cenderung meningkat. Pada tahun 2015 ditemukan kasus pneumonia sebesar 5.724 kasus. Puskesmas 4 Ulu merupakan puskesmas dengan populasi balita tertinggi yang terdapat di Kecamatan Seberang Ulu 1. Temuan kasus pneumonia di wilayah kerja Puskesmas 4 Ulu mengalami peningkatan selama tiga tahun berturut turut yaitu pada tahun 2014 sebesar 3,52\%, pada tahun 2015 sebesar 5,54\% dan meningkat kembali pada tahun 2016 sebesar 5,91\% (Puskesmas 4 Ulu, 2018). 
Dilihat dari aktivitas balita yang lebih sering melakukan kegiatan didalam rumah bersama orang tua dan anggota keluarga, pneumonia yang terjadi pada balita dapat disebabkan oleh lingkungan didalam rumah yang tidak memenuhi syarat. Faktor lingkungan rumah yang dapat mempengaruhi pneumonia salah adalah faktor individu dan lingkungan fisik rumah. Berdasarkan hasil observasi awal, masih banyak rumah di wilayah kerja Puskesmas 4 Ulu yang belum memiliki struktur rumah yang baik dilihat masih banyaknya rumah yang menggunakan bahan dinding kayu, namun beberapa sudah memiliki struktur rumah seperti jenis bahan yang digunakan untuk lantai, dan atap rumah yang sudah baik. Dilihat dari faktor - faktor lingkungan rumah seperti kondisi pencahayaan alami dan kelembaban udaranya, di wilayah puskesmas 4 ulu bervariasi dan juga merupakan daerah yang cukup padat baik bangunan maupun penduduk, dengan jumlah penduduk sebesar 57.680 jiwa dari 3 kelurahan pada tahun 2016.

Berdasarkan dari apa yang telah diuraikan sebelumnya, maka peneliti merasa perlu mengkaji lebih lanjut hubungan antara faktor lingkungan rumah dengan kejadian pneumonia pada balita di Wilayah Kerja Puskesmas 4 Ulu Kota Palembang.

\section{METODE PENELITIAN}

Wilayah kumuh di Kota Palembang terletak pada beberapa titik, seperti di Gandus, Ilir Timur 2 dan Seberang Ulu. Penelitian ini dlakukan di wilayah kerja Puskesmas 4 Kecamatan Seberang Ulu 1. Penelitian ini merupakan penelitian kuantitatif dengan rancangan penelitian menggunakan desain studi kasus kontrol. Populasi adalah keseluruhan objek penelitian. Populasi dalam penelitian ini adalah semua balita yang berada di wilayah kerja puskesmas 4 ulu Kota
Palembang. Sampel adalah objek yang diteliti dan dianggap mewakili seluruh populasi yang memenuhi kriteria inklusi dan eksklusi. Jumlah sampel dalam penelitian ini sebanyak 78 sampel, yang terdiri dari 26 sampel kasus dan 52 sampel kontrol dengan perbandingan 1:2. Sampel kasus pneumonia diambil dari buku register Puskesmas 4 Ulu diambil dari penderita pneumonia pada Bulan Januari Desember tahun 2017, sedangkan sampel kontrol diambil dari balita tetangga terdekat kasus. Variabel bebas yang diteliti terdiri dari berat lahir, riwayat pemberian ASI eksklusif, riwayat imunisasi, luas ventilasi, kepadatan hunian rumah, pencahayaan alami rumah, suhu, kelembaban, keberadaan anggota keluarga merokok serta penggunaan obat anti nyamuk bakar. Karakteristik responden seperti berat lahir, riwayat ASI eksklusif, status imunisasi, kepadatan hunian, keberadaan anggota keluarga merokok dan penggunaan obat anti nyamuk bakar diambil dengan kuisioner yang terstruktur, sedangkan pengambilan data karakteristik rumah seperti luas ventilasi menggunakan roll meter, pencahayaan alami menggunakan luxmeter, suhu dan kelembaban menggunakan thermohygrometer. Dalam penelitian ini digunakan beberapa analisis data yaitu analisis univariat, analisis bivariat menggunakan chi-square dan analisis multivariat menggunakan regresi logistik ganda permodelan prediksi dengan software statistika. Penelitian ini dilakukan pada bulan April - Mei 2018.

\section{HASIL DAN PEMBAHASAN}

\section{Karakteristik Responden}

Variabel yang termasuk ke karakteristik balita yaitu berat lahir, riwayat pemberian ASI esksklusif dan status imunisasi (Gambar 1). Dapat diketahui bahwa frekuensi balita dengan berat lahir rendah, tidak memiliki riwayat 
pemberian ASI eksklusif dan tidak alami rumah, suhu ruangan, kelembaban, memiliki status imunisasi lengkap lebih keberadaan anggota keluarga yang banyak pada kelompok kasus merokok, dan penggunaan obat anti dibandingkan pada kelompok kontrol. nyamuk bakar lebih banyak yang tidak Sedangkan dapat diketahui bahwa memenuhi syarat pada kelompok kasus frekuensi variabel luas ventilasi, dibandingkan dengan kelompok kontrol. kepadatan hunian rumah, pencahayaan

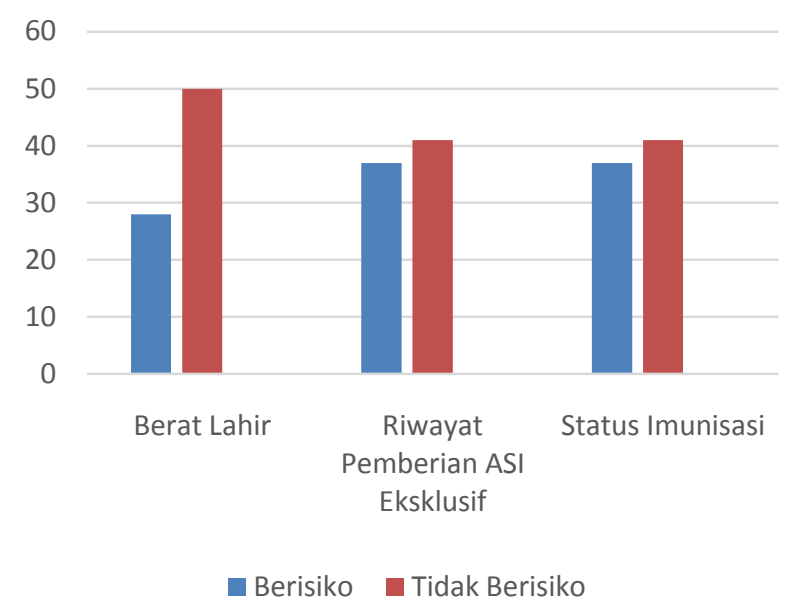

Gambar 1. Karakteristik Responden

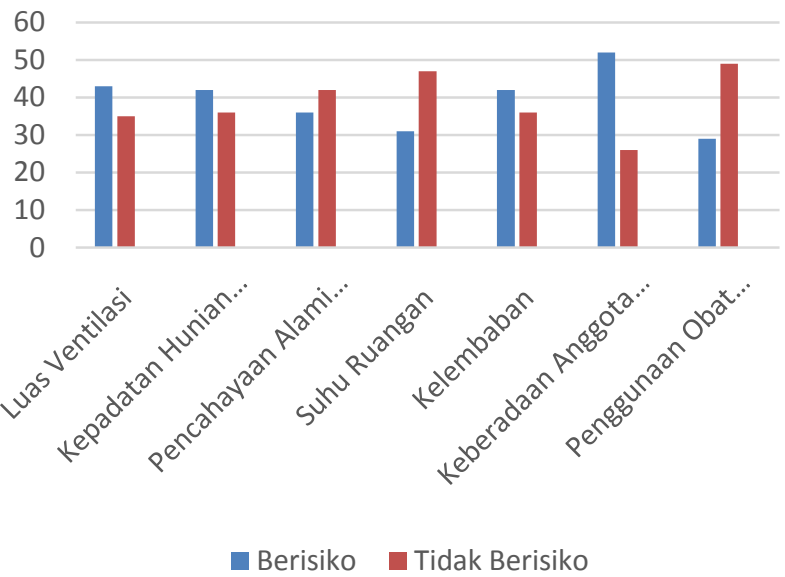

Gambar 2. Distribusi Kondisi fisik rumah 
Tabel 1. Analisis Bivariat

\begin{tabular}{|c|c|c|c|c|c|c|c|c|}
\hline \multirow{2}{*}{ Variabel } & \multicolumn{2}{|c|}{ Kasus } & \multicolumn{2}{|c|}{ Kontrol } & \multirow[t]{2}{*}{$\mathbf{n}$} & \multirow[t]{2}{*}{$\%$} & \multirow[t]{2}{*}{ Pvalue } & \multirow{2}{*}{$\begin{array}{c}\text { OR } \\
(95 \% \mathrm{CI})\end{array}$} \\
\hline & $\mathbf{n}$ & $\%$ & $\mathbf{n}$ & $\%$ & & & & \\
\hline \multicolumn{9}{|l|}{ Berat Lahir } \\
\hline BBLR & 13 & 50,0 & 15 & 28,8 & 28 & 35,9 & \multirow{2}{*}{0,113} & \\
\hline Tidak BBLR & 13 & 50,0 & 37 & 71,2 & 50 & 64,1 & & $(0,930-6,541)$ \\
\hline \multicolumn{9}{|c|}{ Riwayat Pemberian ASI Eksklusif } \\
\hline Tidak ASI & 17 & 65,4 & 20 & 38,5 & 37 & 47,4 & \multirow{2}{*}{0,045} & \multirow{2}{*}{$\begin{array}{c}3,022 \\
(1,132-8,071)\end{array}$} \\
\hline $\begin{array}{l}\text { Eksklusif } \\
\text { ASI Eksklusif }\end{array}$ & 9 & 34,6 & 32 & 61,5 & 41 & 52,6 & & \\
\hline \multicolumn{9}{|l|}{ Status Imunisasi } \\
\hline Tidak Lengkap & 14 & 53,8 & 23 & 44,2 & 37 & 47,4 & \multirow{2}{*}{0,575} & 1,471 \\
\hline Lengkap & 12 & 46,2 & 29 & 55,8 & 41 & 52,6 & & $(0,571-3,787)$ \\
\hline \multicolumn{9}{|l|}{ Luas Ventilasi } \\
\hline TMS & 19 & 73,1 & 24 & 46,2 & 43 & 55,1 & \multirow{2}{*}{0,044} & 3,167 \\
\hline MS & 7 & 26,9 & 28 & 53,8 & 35 & 44,9 & & $(1,138-8,815)$ \\
\hline \multicolumn{9}{|c|}{ Kepadatan Hunian Rumah } \\
\hline TMS & 19 & 73,1 & 23 & 44,2 & 42 & 53,8 & \multirow{2}{*}{0,030} & 3,422 \\
\hline MS & 7 & 26,9 & 29 & 55,8 & 36 & 46,2 & & $(1,228-9,538)$ \\
\hline \multicolumn{9}{|c|}{ Pencahayaan Alami Rumah } \\
\hline TMS & 19 & 73,1 & 17 & 32,7 & 36 & 46,2 & \multirow{2}{*}{0,002} & 5,588 \\
\hline MS & 7 & 26,9 & 35 & 67,3 & 42 & 53,8 & & $(1,970-15,849)$ \\
\hline \multicolumn{9}{|l|}{ Suhu } \\
\hline TMS & 16 & 61,5 & 15 & 28,8 & 31 & 39,7 & \multirow{2}{*}{0,011} & 3,947 \\
\hline MS & 10 & 38,5 & 37 & 71,2 & 47 & 60,3 & & $(1,463-10,643)$ \\
\hline \multicolumn{9}{|l|}{ Kelembaban } \\
\hline TMS & 19 & 73,1 & 23 & 44,2 & 42 & 53,8 & \multirow{2}{*}{0,030} & 3,422 \\
\hline MS & 7 & 26,9 & 29 & 55,8 & 36 & 46,2 & & $(1,228-9,538)$ \\
\hline \multicolumn{9}{|c|}{ Keberadaan Anggota Keluarga Merokok } \\
\hline Ya & 22 & 84,6 & 30 & 59,6 & 52 & 66,7 & \multirow{2}{*}{0,034} & 4,033 \\
\hline Tidak & 4 & 15,4 & 22 & 40,4 & 26 & 33,3 & & $(1,216-13,378)$ \\
\hline \multicolumn{9}{|c|}{ Penggunaan Obat Anti Nyamuk Bakar } \\
\hline Ya & 11 & 42,3 & 18 & 34,6 & 29 & 37,2 & \multirow{2}{*}{0,679} & 1,385 \\
\hline Tidak & 15 & 57,7 & 34 & 65,4 & 49 & 62,8 & & $(0,528-3,637)$ \\
\hline
\end{tabular}

*TMS = Tidak Memenuhi Syarat, MS = Memenuhi Syarat

Hasil penelitian ini menemukan bahwa anak dengan berat lahir anak tidak mempengaruhi kejaan pneumonia pada balita Hasil uji statistik chi square menunjukkan bahwa nilai p adalah 0,113 . Hasil ini sejalan dengan penelitian Rudan dkk. (2013) yang menyatakan bahwa tidak terdapat hubungan yang bermakna secara statistik antara berat lahir dengan kejadian pneumonia pada balita dengan nilai $\mathrm{P}$ value sebesar 0,591. Namun hasil ini berbeda dengan penelitian Nirmolia dkk. (2018) yang menyatakan bahwa risiko kejadian pneumonia pada balita dengan berat badan lahir rendah adalah sebesar 1,28 kali dibandingkan dengan balita yang mempunyai berat badan lahir normal.

Tidak terdapatnya hubungan antara variabel berat lahir dengan kejadian pneumonia pada penelitian ini disebabkan berat lahir tidak berhubungan langsung dengan kejadian pneumonia (Walker dkk., 2013). Berdasarkan hasil observasi yang telah dilakukan dilapangan, sampel pada penelitian baik pada kelompok kasus maupun pada kelompok kontrol memiliki berat lahir normal. Pada saat ini penanganan dan perawatan bayi dengan 
BBLR sudah semakin membaik sehingga bisa mengurangi angka kesakitan dan kematian akibat BBLR. Pemberian nutrisi pada bayi seperti kelengkapan pemberian imunisasi dasar lengkap dan pemberian ASI juga dapat menjadi salah satu dari beberapa penyebab terjadinya kejadian pneumonia pada balita, sehingga pada penelitian ini berat lahir bukan merupakan faktor yang semata-mata menyebabkan kejadian pneumonia.

ASI eksklusif sangat berpengaruh pada daya tahan hidup bayi selama 6 bulan pertama kehidupan. Pada variabel pemberian ASI Eksklusif, hasil uji statistik chi square menunjukkan bahwa nilai $\mathrm{p}=0,045$ yang artinya ada hubungan antara riwayat pemberian ASI eksklusif dengan kejadian pneumonia pada balita. Hasil penelitian ini sejalan dengan penelitian Ghafini (2015) yang didapatkan bahwa ada hubungan antara pemberian ASI eksklusif degan kejadian pneumonia di wilayah kerja Puskesmas Pedan Klaten $(\mathrm{p}=0,014)$. Balita yang tidak mendapatkan ASI eksklusif mempunyai risiko terkena pneumonia sebesar 3,095 kali dibandingkan balita yang mendapatkan ASI eksklusif. Hal ini diperkuat dengan penelitian Fanada (2012) yang menyimpulkan ada hubungan antara pemberian ASI eksklusif dengan kejadian pneumonia pada balia dimana $\mathrm{p}=0,001$. Upaya yang dapat dilakukan dalam mengendalikan kejadian pneumonia pada ibu - ibu di wilayah kerja Puskesmas 4 Ulu Kota Palembang yaitu dengan memberikan penyuluhan tentang manfaat ASI eksklusif, pentingnya pemberian ASI eksklusif, serta kelebihan ASI eksklusif sehingga dapat meningkatkan pengetahuan ibu - ibu. Menganjurkan ibu - ibu untuk memberikan ASI eksklusif kepada bayinya untuk mencegah terjadinya pneumonia atau penyakit lainnya.

Hasil penelitian ini menunjukkan tidak terdapat hubungan antara status imunisasi dengan kejadan pneumonia pada balita. Hasil penelitian ini sejalan dengan penelitian (Rudan dkk., 2013) yang menunjukkan tidak ada hubungan antara status imunisasi dengan kejadian pneumonia pada balita ( $\mathrm{p}=0,341)$. Namun hal ini tidak sejalan dengan penelitian Wang dkk. (2013) yang menyatakan bahwa ada hubungan yang signifikan antara status imunisasi dengan kejadian pneumonia pada balita dengan nilai $\mathrm{p}$ sebesar 0,000) dan balita dengan status imunisasi tidak lengkap mempunyai peluang mengalami pneumonia sebanyak 0,79 kali dibanding balita dengan status imunisasi lengkap. Peneliti berasumsi bahwa tidak adanya hubungan antara status imunisasi dengan kejadian pneumonia pada balita disebabkan oleh adanya status imunisasi bayi lengkap tetapi tidak didukung nutrisi yang baik bayi akan mudah terserang infeksi dan penyakit, ditambah faktor lingkungan rumah yang tercemar oleh polusi udara yang menjadikan faktor terjadinya pneumonia pada bayi.

Luas ventilasi menunjukkan hubungan yang bermakna dengan kejadian pneumonia pada balita. Ventilasi rumah mempunyai perananan yang sangat penting sebagai sarana sirkulasi udara segar masuk kedalam masuk dan udara kotor keluar rumah dengan tujuan menjaga kelembaban udara didalam rumah. Hasil uji statistik chi square menunjukkan bahwa nilai $\mathrm{p}$ adalah 0,044 . Hasil penelitian ini sejalan dengan penelitian (Chen dkk., 2011) yang menyatakan bahwa terdapat hubungan yang bermakna secara statistik antara luas ventilasi rumah dengan kejadian pneumonia pada balita $(\mathrm{P}$ value $=0,004)$ dan balita yang tinggal dirumah dengan luas ventilasi yang tidak memenuhi syarat memiliki peluang 9,3 kali terkena pneumonia dibandingkan balita yang tinggal dirumah dengan luas ventilasi yang memenuhi syarat. Berdasarkan hasil 
observasi dilapangan sebagian besar perbandingan luas ventilasi rumah responden tidak sebanding dengan luas lantai, selain itu juga masih banyak rumah responden yang ventilasinya tidak dibuka sehingga terhalangnya cahaya matahari untuk masuk kedalam rumah. Hal ini dapat membahayakan penghuni rumah terutama balita yang rentan terhadap penyakit yang disebabkan oleh mikroorganisme yang timbul karena pencemaran udara (Zhuge dkk., 2018).

Hasil uji statistik chi square pada variabel kepadan hunian rumah menunjukkan bahwa nilai $\mathrm{p}=0,030$ yang artinya ada hubungan antara kepadatan hunian rumah dengan kejadian pneumonia pada balita. Hasil penelitian ini sejalan dengan penelitian Wang dkk. (2016) yang menyatakan bahwa rumah responden yang tergolong dalam hunian padat mempunyai risiko 4,38 kali lebih besar untuk terjadinya pneumonia balita dibandingkan dengan rumah yang tergolong dalam kepadatan hunian yang telah memenuhi standar. Dari hasil observasi lapangan, ditemukan bahwa sebagian besar responden tinggal dalam rumah yang ukurannya tidak sebanding dengan jumlah penghuni rumah tesebut. Dimana dalam satu rumah masih banyak terdapat lebih dari 1 kepala keluarga, sehingga dalam satu rumah menjadi padat penghuni dan tidak memberikan kenyamanan dalam bergerak serta terasa sesak. Hal ini menyebabkan semakin padat penghuni rumah maka perpindahan penyakit khusunya penyakit lewat udara semakin mudah dan cepat terutama pada balita yang rentan terhadap penularan penyakit. Oleh sebab itu, rumah yang padat dapat meningkatkan risiko kejadian pneumonia pada balita.

Pada variabel pencahayaan alami rumah hasil uji statistik chi square menunjukkan bahwa nilai $\mathrm{p}=0,002$ yang artinya ada hubungan antara pencahayaan alami rumah dengan kejadian pneumonia pada balita. Hasil penelitian ini sejalan dengan penelitian Zhuge dkk. (2018) yang menyatakan bahwa pencahayaan alami dengan kejadian pneumonia memiliki hubungan yang bermakna dengan kejadian pneumonia $(\mathrm{p}=0,044)$ dan anak balita yang tinggal dirumah dengan pencahayaan yang tidak memenuhi syarat memiliki risiko terkena pneumonia sebesar 2,82 kali lebih besar dibandingkan dengan anak balita yang tinggal dirumah dengan pencahayaan yang memenuhi syarat. Fakta dilapangan menunjukkan bahwa sebagian besar jendela rumah dan kamar balita tidak dibuka dan beberapa jendela bersifat permanen, selain itu juga jarak rumah yang berdekatan menyebabkan cahaya yang masuk terhalang oleh bangunan rumah tetangga, sehingga kurangnya sinar matahari yang masuk kedalam ruma. Kurangnya sinar matahari yang masuk dalam rumah selain menyebabkan kurang nyaman juga merupakan media yang baik untuk berkembangnya penyakit terutama pneumonia.

Suhu dapat mempengaruhi kejadan pneumonia pada balita. Hasil uji statistik chi square menunjukkan bahwa nilai $\mathrm{p}=$ 0,011 yang artinya ada hubungan antara suhu dengan kejadian pneumonia pada balita. Hasil ini sejalan dengan penelitian Sun dkk. (2017) yang hasil uji statistik terdapat hubungan yang bermakna antara suhu dengan kejadian pneumonia pada balita $(\mathrm{p}=0,023)$. Pada suhu tertentu memungkinkan pertumbuhannya terhambat bahkan tidak tumbuh sama sekali atau mati namun juga dapat tumbuh dan berkembangbiak dengan sangat cepat. Hal inilah yang membahayakan karena semakin sering anak berada dalam ruangan dengan kondisi tersebut dalam jangka waktu yang lama maka akan terpapar faktor risiko tersebut, akibatnya semakin besar peluang anak untuk terjangkit pneumonia (Nirmolia dkk., 
2018; Wang dkk., 2013; Zhuge dkk., 2018).

Pada variabel kelembaban hasil uji statistik chi square menunjukkan bahwa nilai $p=0,030$ yang artinya ada hubungan antara kelembaban dengan kejadian pneumonia pada balita. Hasil penelitian ini sejalan dengan penelitian Sun dkk. (2017), hasil uji statistik terdapat hubungan yang bermakna antara kelembaban dengan kejadian pneumonia pada balia $(p=0,001)$. Balita yang tinggal dirumah dengan tingkat kelembaban yang tidak memenuhi syarat memiliki peluang 3,9 kali terkena pneumonia dibandingkan dengan balita yang tinggal dirumah dengan tingkat kelembaban yang memenuhi syarat. Berdasarkan observasi dilapangan, sebagian besar balita menghabiskan waktu sepanjang hari di ruangan keluarga dan kamar dan sebagian besar jendela tidak dibuka. Ventilasi sangat berkaitan erat dengan kelembaban, ventilasi rumah yang tidak pernah dibuka akan menghalangi cahaya matahari untuk masuk ke dalam rumah, sehingga kelembaban didalam ruangan akan meningkat. Kelembaban diluar rumah secara alami dapat mempengaruhi kelembaban di dalam rumah. Sebagian responden tinggal di dekat sungai, hal ini yang akan mempengaruhi tingkat kelembaban menjadi tinggi. Ruang yang lembab memungkinkan untuk tumbuhnya mikroorganisme penyebab pneumonia (Nguyen dkk., 2017).

Keberadaan anggota keluarga yang merokok merupakan salah satu faktor yang mempengaruhi pneumonia pada balita dan hasil uji statistik pada penelitian ini $\mathrm{p}$ adalah 0,034 . Hasil penelitian ini sejalan dengan penelitian Mentese dkk. (2015) yang menjelaskan bahwa balita yang tinggal dirumah dengan keberadaan perokok memilki risiko 2,9 kali lebih besar untuk terkena pneumonia dibandingkan dengan balita yang tinggal dirumah yang tidak memiliki keberadaan perokok didalam rumah dan keberadaan anggota keluarga merokok dalam rumah meningkatkan risiko menderita pneumonia 1,159 kali hingga 7,503 kali. Berdasarkan observasi lapangan, sebagian besar responden baik pada kelompok kasus maupun kelompok kontrol memiliki anggota keluarga merokok dalam rumah, sebagian besar dari mereka adalah orang tua laki - laki balita itu sendiri. Banyaknya jumlah perokok dan jumlah batang rokok yang dihisap didalam rumah akan sebanding dengan banyaknya penderita kesehatan. Asap rokok bukan hanya menjadi penyebab langsung kejadian penyakit pernapasan pada balita, tetapi menjadi faktor tidak langsung yang diantaranya dapat melemahkan daya tahan tubuh balita (Wen dan Zhang, 2017). Jadi, keberadaan anggota keluarga yang merokok dirumah merupakan salah satu faktor risiko untuk terjadinya pneumonia pada balita.

Sedangkan variabel penggunaan obat anti nyamuk bakar tidak menunjukkan hubungan yang bermakna dengan kejadian pneumonia pada balita. Hasil uji statistik chi square terdapat nilai $\mathrm{p}=0,679$. Hasil penelitian ini sejalan dengan penelitian Chen dkk. (2011) yang menyatakan bahwa tidak terdapat hubungan antara penggunaan obat anti nyamuk bakar dengan kejadian pneumonia pada balita. Namun hasil penelitian ini tidak sejalan dengan penelitian Nguyen dkk. (2017) yang menyatakan bahwa ada hubungan yang signifikan antara penggunaan obat nyamuk bakar dengan kejadian pneumonia pada balita dan balita yang tinggal dirumah dengan menggunakan obat nyamuk bakar mempunyai risiko 9,000 kali lebih besar menderita pneumonia dibandingkan dengan balita yang tinggal dirumah dengan tidak menggunakan obat anti nyamuk bakar. Tidak adanya hubungan antara penggunaan obat anti nyamuk bakar 
dengan kejadian pneumonia menunjukkan bahwa penggunaan obat anti nyamuk bakar bukan merupakan faktor yang langsung mempengaruhi kejadian pneumonia. Berdasarkan hasil observasi yang didapat dilapangan, banyak dari responden tidak memakai obat anti nyamuk bakar, melainkan lebih memilih untuk menggunakan obat anti nyamuk berbentuk lotion dan menggunakan kelambu. Sebagian responden juga banyak yang tidak menggunakan obat anti nyamuk karena mengaku tidak adanya nyamuk ditempat tinggal mereka.

Tabel 2. Hasil Analisis Multivariat

\begin{tabular}{lcc}
\hline \multicolumn{1}{c}{ Variabel } & Pvalue & OR (95\% CI) \\
\hline Penggunaan Obat Anti Nyamuk Bakar & 0,583 & $0,605(0,101-3,632)$ \\
\hline Riwayat ASI Eksklusif & 0,627 & $1,417(0,347-5,786)$ \\
\hline Luas Ventilasi & 0,507 & $1,714(0,349-8,423)$ \\
\hline Keberadaan Anggota Keluarga Merokok & 0,429 & $1,992(0,361-10,982)$ \\
\hline Kepadatan Hunian Rumah & 0,290 & $2,305(0,491-10,824)$ \\
\hline Kelembaban & 0,193 & $2,932(0,580-14,831)$ \\
\hline Suhu & 0,136 & $3,182(0,693-14,605)$ \\
\hline Berat Lahir & 0,082 & $3,856(0,842-17,658)$ \\
\hline Pencahayaan Alami Rumah & 0,007 & $10,165(1,887-54,743)$ \\
\hline
\end{tabular}

Hasil analisis multivariat menunjukan bahwa variabel pencahayaan alami rumah merupakan variabel yang paling dominan berhubungan dengan kejadian pneumonia pada balita. Balita yang tinggal dirumah dengan tingkat pencahayaan yang tidak memenuhi syarat berisiko 10,165 kali untuk menderita pneumonia dibandingkan balita yang tinggal dirumah dengan tingkat pencahayaan yang memenuhi syarat, dapat diyakini $95 \%$ pada populasi umum balita yang tinggal di rumah dengan tingkat pencahayaan alami rumah yang tidak memenuhi syarat meningkatkan risiko terkena pneumonia 1,887 kali hingga 54,743 .

\section{KESIMPULAN}

Hasil analisis data menunjukkan dari 10 variabel yang diteliti terdapat 7 variabel yang berhubungan yaitu riwayat pemberian ASI eksklusif, luas ventilasi, kepadatan hunian rumah, pencahayaan, suhu, kelembaban dan keberadaan anggota keluarga yang merokok.
Berdasarkan hasil analisis multivariat, variabel pencahayaan merupakan variabel yang paling berhubungan dengan OR 10,165 .

Pencahayaan alami rumah sangat mempengarhi suhu dan kelembaban, dimana rumah dengan pencahayaan yang kurang dapat menyebabkan suhu dan kelembaban ruangan meningkat dan menjadi sumber yang baik bagi bibit -bibit penyakit untuk berkembangbiak. Rumah tangga dengan kondisi lingkungan yang masih belum memenuhi syarat seperti tingkat pencahayaan yang minim dapat berisiko menyebabkan terjadinya pneumonia pada balita, sehingga disarankan melakukan upaya renovasi agar memenuhi persyaratan rumah tangga yang sehat.

\section{UCAPAN TERIMA KASIH}

Terimakasih kepada Universitas Sriwijaya sebagai pemberi dana pada Hibah Penelitian Sains dan Teknologi dosen muda Universitas Sriwijaya. 


\section{DAFTAR PUSTAKA}

Chen, Y., Deng, W., Wang, S.-M., Mo, Q.-M., Jia, H., Wang, Q., Li, S.G., Li, X., You, B.D., Liu, C.J., Zhan, Y.Q, Ji, Q., Lopez, A.L. \& Wang, X.-Y. (2011). Burden of Pneumonia and Meningitis Caused by Streptococcus pneumoniae in China among Children under 5 Years of Age: A Systematic Literature Review. PLoS One, 6(11), e27333. doi: 10.1371/journal.pone.0027333.

Dinkes Palembang. (2016). Profil Kesehatan Kota Palembang. Dinas Kesehatan Kota Palembang, Palembang.

Li, Z., Wen, Q., \& Zhang, R. (2017). Sources, health effects and control strategies of indoor fine particulate matter (PM2.5): A review. Science of The Total Environment, $\quad 586, \quad 610-622 . \quad$ doi: https://doi.org/10.1016/j.scitotenv.2017.02.029.

Mentese, S., Mirici, N. A., Otkun, M. T., Bakar, C., Palaz, E., Tasdibi, D., Cevizci, S. \& Cotuker, O. (2015). Association between respiratory health and indoor air pollution exposure in Canakkale, Turkey. Building and Environment, 93, 7283. doi: https://doi.org/10.1016/j.buildenv.2015.01.023.

Nguyen, T. K. P., Tran, T. H., Roberts, C. L., Fox, G. J., Graham, S. M., \& Marais, B. J. (2017). Risk factors for child pneumonia - focus on the Western Pacific Region. Paediatric Respiratory Reviews, 21, 95-101. doi: https://doi.org/10.1016/j.prrv.2016.07.002.

Nirmolia, N., Mahanta, T. G., Boruah, M., Rasaily, R., Kotoky, R. P., \& Bora, R. (2018). Prevalence and risk factors of pneumonia in under five children living in slums of Dibrugarh town. Clinical Epidemiology and Global Health, 6(1), 14. doi: https://doi.org/10.1016/j.cegh.2017.07.004.

Puskesmas 4 Ulu. (2018). Profil Puskesmas 4 Ulu Palembang. Puskesmas 4 Ulu, Palembang.

Rudan, I., O’brien, K. L., Nair, H., Liu, L., Theodoratou, E., Qazi, S., Lukšić, I., Fischer Walker, C.L., Black, R.E. \& Campbell, H. (2013). Epidemiology and etiology of childhood pneumonia in 2010: estimates of incidence, severe morbidity, mortality, underlying risk factors and causative pathogens for 192 countries. Journal of global health, 3(1).

Sun, C., Huang, C., Liu, W., Zou, Z., Hu, Y., \& Shen, L. (2017). Home dampnessrelated exposures increase the risk of common colds among preschool children in Shanghai, China: Modified by household ventilation. Building and Environment, 124, 31-41. doi: https://doi.org/10.1016/j.buildenv.2017.07.033.

Walker, C. L. F., Rudan, I., Liu, L., Nair, H., Theodoratou, E., Bhutta, Z. A., O'Brien, K.L., Campbell, H. \& Black, R. E. (2013). Global burden of childhood pneumonia and diarrhoea. The Lancet, 381(9875), 1405-1416.

Wang, S. F., Yang, Z., Yu, P., Hui Wen, Z., \& Yan Lin, Z. (2016). Prevalence and Risk Factors of Primary Drug-Resistant Tuberculosis in China. Biomedical and Environmental Sciences, 29(2), 91-98. doi: https://doi.org/10.3967/bes2016.010.

Wang, T., Zhao, Z., Yao, H., Wang, S., Norback, D., Chen, J., Ma, J.F., Ji, X., Wang, L, \& Sundell, J. (2013). Housing characteristics and indoor environment in relation to children's asthma, allergic diseases and pneumonia in Urumqi, China. Chinese Science Bulletin, 58 (34), 4237-4244. 
WHO. (2010). Housing-related health risks. Retrieved 6 Desember, 2018, from https://www.who.int/sustainable-development/cities/health-risks/slums/en/.

WHO. (2016). Pneumonia Fact Sheets. Retrieved 20 Mei, 2018, from http://www.who.int/mediacentre/factsheets/fs331/en/.

Zhuge, Y., Qian, H., Zheng, X., Huang, C., Zhang, Y., Zhang, M., Li, B., Zhao, Z., Deng, Q., Yang, X., Sun, Y., Wang, T., Zhang, X. \& Sundell, J. (2018). Residential risk factors for childhood pneumonia: A cross-sectional study in eight cities of China. Environment International, 116, 83-91. doi: https://doi.org/10.1016/j.envint.2018.03.022. 